\title{
REFLECTIONS AND PATHWAYS
}

\section{The costs and benefits of mercantilist warfare}

\author{
PATRICK KARL O'BRIEN \\ London School of Economics and Political Sciences
}

\begin{abstract}
This article offers an architectural blueprint for the study of economic connections between warfare in the early modern period and the long-term growth of Europe's competing national economies. It surveys and critically investigates the concepts derived mainly from economic theory and the statistical evidence accessible in primary and secondary sources for the investigation of this meta-problem for students of economic theory.
\end{abstract}

Keywords: costs, benefits, destruction and augmentation of capital and labour

JEL classification: $\mathrm{BI}_{1}, \mathrm{~F}_{\mathrm{I}}, \mathrm{F}_{5}, \mathrm{H}_{\mathrm{I}}, \mathrm{N}_{4}$

Political and military historians tend to ignore detailed investigations into the economic consequences of warfare before the era of the Revolutionary and Napoleonic Wars. They concentrate upon investigations into the origins, political effects or the process involved in waging war (Gatt 2006). This may well be because generalisations about the economic impact of wars remain extremely difficult to validate with reference to plausible empirical evidence which might represent a measurable difference that active involvement in armed conflict with rival powers made to the long-term progress of a national economy (Voightlander and Voth 20I2). Yet what might have occurred to economies without participation in war is a question that arises for nearly every sector of most national economies that we begin to consider. War may delay, accelerate, arrest or totally transform prospects for economic development. Occasionally (and this may be the case for 'smaller and shorter' wars) their influence could turn out to be neither here nor there.

Counterfactual modes of reasoning emerge explicitly in the economists' methods of analysing connections between war and economic progress. Impatient with history, they cut through detailed investigation by positing the continuation of pre-war

P. K. O'Brien, Emeritus Professor of Economic History, University of London; and Department of Economic History, London School of Economics and Political Sciences, Houghton Street, Aldwych, London WC2A 2AE, UK; email: patrick.obrien@sant.ox.ac.uk. 
trends in rates of growth for national income, industrial production and consumption per head. They then typically proceed to assert that: (a) in the absence of war such trends would have persisted; (b) deviations from interpolated changes over time based upon dubious data represent the costs of war; and (c) that the influence of war ceases once national economies are back on their pre-war paths for growth. Such methods were used to support the claims of Arthur Lewis that the world 'lost' four and a half years' industrial output and five years' agricultural output from the First World War (Lewis I953). They helped Claudia Goldin and Frank Lewis to suggest that as late as I9I 3 per capita consumption in the south of the United States remained seriously and measurably depressed by the effects of the Civil War (Goldin and Lewis I975). Such procedures enabled Simon Kuznets to separate countries that did well out of the Second World War from those that fared badly (Kuznets I954).

Historians are unlikely to be convinced that trends in production or consumption can be defined or represented in any 'scientific way', let alone extrapolated forward on the basis of accessible and reliable statistics for longer or shorter runs of so-called 'typical' pre-war years (Broadberry et al. 2015). They will not be inclined to accept assumptions that the influence of war 'ceases' once an economy is assumed to be back on some kind of normal and teleological trajectory for long-run growth. They will insist upon investigating the enduring economic impact of wars step by step, sector by sector, institution by institution (Aerts and Crouzet I990). Above all, they will treat with condescension the compression of long-run historical change into linear models of path-dependent growth. They will continue to support assumptions associated with Schumpeterian theory, namely that economic growth is a cyclical process and that the nature and intensity of crucial cycles vary in their chronologies and across economies in ways that have exercised significant degrees of influence upon trends and patterns of national development (Goldstein I988; Schumpeter I939).

Connected to a plausible pre-war trajectory macro-statistical exercises draw attention to a common fact, namely: war usually reduced a country's capacity for steady growth; that deprivation (measured in terms of private consumption foregone) rises to a maximum in wartime, but then steadily diminishes as recovery carries economies forward again (Sandler and Hartley I995). Wars were, furthermore, usually accompanied by shifts in the relative positions, potential and prospects for national economies within the global economy at large (Modelski I987; Findlay and O'Rourke 2007). Finally, choices of chronologies and time periods for the analysis also predetermine the assessment of historical outcomes. Some attempt at a clear separation should be made between short and enduring effects of war. During hostilities and while its aftermath is being 'cleaned up', war clearly disrupts 'normal' economic activity. By no means everything that occurs during 'years of conflict and transition' (peace to war and back to peace again) had significant long-run economic effects upon the growth of national or national economies. My reflections are concerned basically with long-run growth and will bypass the ups and downs experienced by economies occasioned by disruptions in wartime (Broadberry and Harrison 2005). 
For a consideration of cycles and trajectories that may retrospectively be validated as trends towards structural change, cost benefit analysis (as developed by modern economics) provides an illuminating taxonomy and vocabulary to start an analysis. Initial and relevant questions to pursue are, for example: what were the 'costs' of war? How are they best defined and added up? What were the economic benefits and how far can they be quantified? Most literature on the impact of wars remains concerned with their 'costs'. Economic benefits have, until recently, been ignored because liberal scholars have been reluctant to admit that engagement, even in early modern warfare, could pay off (Silberner 1946; Liberman I998; Voightlander and Voth 20I2). Yet throughout the mercantilist era, which preceded the wars against Revolutionary France, from I793 to I 8 I 5, positive connections between the successful prosecution of war, political stability, state building and commercial success were well understood by European statesmen and intellectuals of the day (Magnuson 2009; Reinert 20 I I). Latterly, the material gain that has sustained a strong economic and historical interest is the link between war and technological breakthroughs (Ruttan 2006). For earlier centuries not much of that discussion is or could be definitely settled. Spinoffs from military, compared to civilian, demand seems to have been too weak, too diffuse or too specifically designed to have imparted a powerful stimulus to pre-modern technological innovation and development (Hoffman 20I6; Sandler and Hartley 2007).

Estimates for the total costs of wars can be found in many histories of warfare. They operate with commonsensical definitions and offer balance sheets. Obviously costs are imputed to those who actually paid the bills: for example, the costs to Britons from their monarch's decision to participate in wars to check the dynastic ambitions of Louis XIV (I688-97 and I703-I3). The sums spent by governments on their armed forces may or may not be recorded in comprehensive budget accounts. Nevertheless, these costs should include only incremental expenditures from engagement in each particular war. For that purpose the easiest assumption to work with is to subtract pre-war military and naval outlays (growing at a certain rate) from actual war and immediate post-war expenditures. The net figures could then be deflated to produce estimates in constant prices for a group of years before a war or 'discounted' from an investor's perspective to produce totals expressed in terms of present or prewar values. If available and properly calibrated totals of budgetary expenditures might be converted to a common currency (ducats) or some tangible international value (grams of silver, tons of grain, or days of labour time) in order to render total outlays on war comparable across countries.

Two other direct costs should also be included in estimates defined to represent the total cost of any war: human casualties and the value of productive assets destroyed and damaged by enemy action. Neither is easy to define, let alone measure. For example, any published figures for military, naval and civilian casualties occasioned 
by early modern wars need to be refined in several ways. First, civilian deaths (which often turned out to be the highest proportion of deaths attributable to conflict) should be scaled down to take account of epidemics, famines and death rates among national populations over a relevant peacetime trajectory. Furthermore, and since the deaths and wounding of large numbers of soldiers and sailors occurred at some remove from actual combat, figures of dead and wounded personnel as recorded for the armed forces also need to be adjusted for 'normal' death and accident rates among relevant age groups. Finally, even these gross totals need to take account of 'birth deficits' flowing from diminished conception rates, contingent upon the mobilisation of young males into the armed forces. Birth deficits will be complex to estimate and if family size was restored by a post-war baby boom, the allowance for this factor could turn out to be small (Clodfelter 2002).

Research and careful calculations might produce rough national totals of the dead and wounded soldiers and sailors, unborn men and women and, above all, of the deaths from diseases carried and violence perpetrated by armies marauding among civilian populations during times of war. The interest in comparing such estimates across countries and through time, war by war, is evident in the literature. Just how 'bloody' were the Revolutionary and Napoleonic Wars? It is the case that on a per capita basis more British personnel, both armed and civilians, died in order to contain Napoleon than to defeat Hitler (Cookson 1987). For historians of economic growth the crass question to ask is: what was the economic value of all those dead, wounded and unborn people (military, naval and civilian)? The answers again rest upon rather simplistic calculations and guesswork. For example, the arithmetic of such exercises could involve: (a) converting wounded into dead people (e.g. counting two wounded as equal to one dead soldier); (b) estimating the average years of working life potentially available at times of death (e.g. a young man killed at the battle of Leipzig aged 20, hypothetically lost, say, 25 years of employment); (c) assessing the value of all the skills lost as casualties of war; (d) multiplying civilian casualties by appropriate sets of variable national wage rates. Paradoxically, this historical arithmetic implies that in I 8 I 5 a dead Dutch soldier could be valued at, say, three times the sum imputable to a dead Russian soldier (Dincecco and Onorato 20I6). If such calculations ever became feasible, historians would then be placed to offer 'plausible conjectures' for the values of 'lost numbers or generations' of unskilled and skilled labour for an economy. Nothing appears to have been published by economists or economic historians that could be represented as a comprehensive estimate for the cost of human capital destroyed and disabled by war. Instead, some cliometricians have concentrated on the benefits from improvements to the land-labour ratios from higher death rates emanating from violence and the diseases diffused by early modern warfare among Europe's societies and economies depicted as Malthusian. They couple that connection to additional benign effects for long-run growth that again were assumed to flow from rising levels of 'urbanisation' that occurred as rural populations fled to towns to escape the violence and predation of marauding armies (Voigtlander and Voth 20I3; Dincecco and Onorato 20I6). 
To define and measure how a nation's fixed capital (machinery, social overhead capital, housing, transport, equipment, etc.) might have been affected by war seems even more complex to estimate (Overy I997). Leaving aside the possibly insurmountable problem of finding useable statistical information, conceptually historians are required to draw up balance sheets of degrees to which wars operated to decrease or to increase the pre-war values of stocks of capital accumulated and utilised by national economies. On the minus side would be listed: the values of destroyed, damaged and enforced transfers of property to the enemy; reduced rates of repair and maintenance; losses related to lower rates of civilian capital formation - calculated again with reference to some postulated trend rate of capital formation over some preselected but defensible peacetime period (Broadberry I988). On the positive side the balance sheet should include gains from predation, reparations, and above all from the enhanced security of property that flowed from victories over enemy powers. For example, Napoleon's success in battles against Prussia, Austria and Russia made the world safer for French capital and that should 'in theory' have been reflected in the values of the wealth of France for some years after his famous victories (Bell 2007).

In an era of mercantilist warfare when expenditures on external security can be represented as endogeneous to the process of capital formation it looks almost impossible to draw up comprehensive balance sheets of gains and losses from warfare for any nation's 'capital account' (Findlay 2006). What precisely was the value of Malta acquired by Britain at the Treaty of Vienna in I8I 5 ? By how much was the value of that nation's productive wealth appreciated by the decline of competition from mainland economies for several decades after I 8 I 5 ? How far were the costs of protecting commerce overseas reduced from I 8 I 5 to I9I 4 by the Pax Britannica which followed from Nelson's victory at Trafalgar in I805 (Backhaus 2012)? Even rough estimates for the net costs of damage and destruction to property, particularly to houses, transport, equipment and livestock, might never be constructed. Although historians may assume that the capital utilised by pre-modern agrarian societies may well have been less destructible than the diversity of capital goods utilised by twentieth-century industrial economies (Landers 2003; Hale I985).

There seems to be no way of measuring national long-term gains and losses imputable to early modern warfare (Dincecco and Onorato 20I6). Thus, rough and ready and incomplete statistics cited by historians for their total costs (which include estimates for governmental expenditures on war, together with 'guesses' for the net values of human and physical capital destroyed by military conflict) will, however, remain difficult to interpret. What might it mean for the long-run growth economies to ascertain that Britain spent $£ 600$ to $£ 700$ million to defeat Napoleon - and an amount roughly equivalent to twice its national income for I 80 I? If acceptable estimates could be constructed (which remains unlikely) such costs could then be expressed in pounds or grams of silver per head of population, country by country. They could also be expressed as multipliers of gross domestic products to ascertain the relative burdens incurred by Europe's national economies to defeat their enemies. 


\section{I}

Such exercises are heuristic to design and connect to the long-term economic progress of countries and empires participating in warfare, but as exercises in quantification they look underspecified and conceptually ambiguous. For example, they do not expose real or 'opportunity costs' (outputs foregone or augmented) from the allocation of manpower and investible funds to wage warfare. Let us instead consider if the implications that followed from the reallocation of labour and capital (the two factors of production mobilised for purposes of defence and aggression) might lead to more theoretically sound and statistically secure conclusions.

Manpower in the form of statistics for the numbers of civilian workers recruited into the army and navy has been published by some states (Dincecco 20II). Such numbers (less mercenaries and other foreigners) can be expressed as proportions of national workforces. For example, by i 8 Io- I I the British government had mobilised some 4 to 6 per cent of its male workforce. (In I9I 7 that proportion was much larger30 per cent at least.) Such ratios are revealing, but what historians usually prefer to establish as a 'cost of war' is the net loss of peacetime outputs that flowed from the reallocation of civilians, either into the armed services, or into production for armies and navies. That depended upon how readily national workforces could be restored to peacetime levels by recruitment from the ranks of the unemployed and from those normally classified as outside the labour force (particularly women); by lengthening the work year; by skill dilution and by increasing the mobility of labour. Substitutions for men at the front or at sea certainly tended to occur only in circumstances of war, but they compensated for potential bottlenecks to production. Pre-modern or even modern economies rarely entered wars in states of full employment. Wars not only operated to take up 'slack', they often increased participation rates, particularly amongst women. They also inculcated skills and attitudes which, in several ways, could have enhanced the long-term efficiencies of post-war workforces. Such conjectures will be difficult to quantify, and it is not clear how seriously recruitment into the services during pre-modern wars depleted the supplies of productive labour available to national economies. For some economies the effects of war upon their workforce could even have been positive for long-term growth, particularly if, where and when fears for themselves and their properties prompted rural families to migrate and agglomerate in towns (Zurcher 20I3; Voigtlander and Voth 2013).

For capital as a factor of production, the question most often posed is: what were the effects of the wars on the rate at which societies accumulated stocks of capital for long-term civilian production? The impact of damage, destruction, enforced transfers and changes in the security of property (both malign and benign) continue to seem unmeasurable. It is probable that urgent military demands stimulated the formation of productive capacity, some of which remained useful only for the specific purposes of a particular combat, but some retained an economic value after the termination of hostilities. Historians will not know how much capital (created for the 
armed services) was relocated into civil production at the end of wars, or continued to be used by the forces for the protection of a nation's security and its wealth. Expenditures on weapons, ships, buildings etc. to wage a war cannot be simplistically represented as 'unproductive' for long-term capital formation (Contamine 2000).

Thus, assessments of connections between investment and warfare turn largely on the contested issue of what happened to net civilian capital formation during and after major wars. How far was private investment depressed by demands from states for the funds required for enlarged military and naval expenditures? In some theoretical models designed to simulate wartime financial processes, borrowing by governments 'crowds out' capital formation for the civilian economy. States bid away available supplies of investible funds and private capital formation slumps. By the end of hostilities, the economy is left with a depleted stock of capital compared to the level it would (counterfactually) have attained in the absence of government borrowing undertaken to engage effectively in warfare (Boskin I987; O’Brien 20 I Ia, b).

Damaging qualifications, however, have been made to the crowding out hypothesis in its more extreme forms because net capital formation clearly continued in several, but not all sectors of wartime economies. Rates of private savings which flowed as loans to the state or continued to support gross domestic investment expenditures tended to rise in wartime and private investment has no invariant inverse relationship to government borrowing over the short term (Friedman I984; Edelstein I990). Economists have protected their models with counterfactuals which postulate that (in the absence of war) the share of gross investment to gross national income could have risen, but this defence is difficult to substantiate and, in several cases, the rise in national savings ratios seems too large to be explained away by some 'latent investment' potential creamed off to finance war (Mokyr I989). Furthermore, examples of post-war mini-booms and examples of rapid recovery do not suggest that stocks of productive capital were invariably and significantly depleted by the reallocation of investible funds into expenditures on the armed forces.

Thus, instead of 'crowding out', there may be a paradox to explain - how did it come about that flows of savings for outlays on armed forces and for private investment could be maintained at surprisingly high rates both in wartime and over potentially immediate post-war years? Economic historians now expect to find elements for an explanation by making two valid observations. First that public expenditure on rearmament and war could well have carried some European economies closer to full employment. For several industries wartime demand led to more intensive and efficient use of resources and to the more rapid diffusion, adaptations and improvements to advanced technologies in order to cope with intensified pressures on existing capacity (Vries 20 I 5). Thus, to some extent funds borrowed for the armed forces came from the extra output that had emerged as a response to augmented wartime levels of demand. In this 'Keynesian' perspective, war, to some degree, paid for itself and the potential adverse effects of crowding out and reallocation of resources were mitigated (Harrison 20 I4). Secondly, savings rates appear to have been unusually responsive to rather modest upswings in interest rates (Neal I990; Bonney I995). 
Prospects for longer-term capital gains helped - provided governments could maintain confidence in victory and secure a potentially profitable peace treaty. Patriotism (or, as economists might prefer, a heightened appreciation of a need for the protection of private wealth) also operated to increase savings by the rich. Wartime taxes on luxuries and shortages of imports and other goods, normally consumed by the affluent classes, reinforced their propensities to save. Furthermore, wartime taxation often became regressive in its social incidence. Thus, the accumulation of public debt redistributed income from social groups with lower, to those with higher propensities to save and invest. While wartime inflations (which result from failures by some states to raise anything but a small proportion of the money required to pay for these wars by taxation) tended to be marked by lags of wages behind prices, which again exercised regressive effects on income distribution, but potentially favourable influences upon investment (Torres Sánchez 2007). Finally, financial intermediation may well have improved in wartime. Banks and other institutions operating within a framework of an elastic expansion in the money supplies, stimulated by intensified military and naval demands for credit, attracted and channelled savings more effectively into the coffers of governments without rationing credit to businessmen. The accumulation of government debt could have promoted institutional innovation in the financial sector and tapped into some latent potential for savings (Caselli 2008; Ventura and Voth 2015).

To sum up: in time of war a state's overall economic strategy seems simple enough to represent. Governments endeavoured to maximise the growth of national income and to acquire the largest possible share for military and naval operations. Consistent with that objective, statesmen and their advisers implemented tax and monetary policies designed to squeeze consumption and to maintain investment upon which loans and tax revenues depend (Sandler and Hartley i995).

Expressed as a share of gross national expenditure, private consumption was depressed and probably remained so for several years after the war, while governments endeavoured to reconstruct economies and clean up the 'mess' left by wartime inflations and the accumulation of sovereign debts (Torres Sánchez 2007). Capital formation was usually less constrained than consumption.

\section{IV}

For several decades 'new' institutional economists have been engaged in restoring institutions to the place they occupied in writings from the German historical school (Hodgson 200I). They have formulated a conceptual vocabulary; promoted the production of case studies and encouraged the construction of dubious 'coefficients of significance' for variations in property rights, transactions costs, legal arrangements and other institutional variables behind observed differences in the performance of pre-modern Eurasian and American economies. This research programme continues to lack anything approximating to a 'foundational theory' for the hegemonic sovereign behind all other subordinate institutions - namely, a 
theory concerned with the formation of developmental states. Such states can be recognised retrospectively as indispensable for the provision of the external security and internal stability required for the maintenance of institutions, laws and cultures promoting long-run growth (Ha-Joon 2007).

Furthermore, latterly modern economics has also conceded that the historical evolution of state capacities for the provision of public goods by states was essentially fiscal and strongly correlated to engagements in warfare (Besley and Persson 20II). The geopolitical preoccupations of pre-modern states were not, however, with economic development, but with external security, internal stability, dynastic survival and the centralisation of power in contexts of persistent geopolitical and mercantilist warfare, as well as conflicts with warlords, aristocrats, urban oligarchies, ecclesiastical authorities, rebellious peasants, disaffected proletarians and other centrifugal forces embodied in structures of local power contained within their contested frontiers.

What generations of political historians have published about state formation across Eurasia over the centuries that preceded the French and Industrial Revolutions and the Great Divergence are analyses of forces working more or less effectively for the centralisation of authority over historically 'conglomerated' polities that differed enormously in territorial extent, geographical diversity, ethnic, cultural and religious composition. They have outlined 'processes of coercion, co-option and collaboration evolving, failing and succeeding over centuries from I4I5-I8I5'. They have also observed that the technologies, flows of information and organisational capacities available to states for the regularised implementation, monitoring and auditing of central policies remained primitive and became less and less effective as distance from the centres of power increased (Dincecco 20I I; Gennaioli and Voth 20I5).

Neither history nor social science offers much by way of theoretical insights into factors and processes promoting fiscally successful trajectories for state formation. Historians who remain sceptical about 'enlightenment correlations' between 'constitutions for liberty' and 'constitutions for economic progress' have looked for heuristic insights that might be exposed by way of 'reciprocal comparisons' of states formation, both in the West and latterly between the Occident and the Orient (Epstein 2000; Hiu 2005).

Operating within Marc Bloch's paradigm, they continue to explore a Weberian hypothesis, namely, that the firms, farms, investors, entrepreneurs and innovators, operating within Europe's mercantilist order and ideology of state formation, derived 'unintended advantages' from that war-prone regime, compared to their counterparts operating within imperial frameworks for economic activity maintained by oriental empires to the east (Yun-Casalilla and O'Brien 20I3).

Unfortunately, the range and chronological runs of data required to validate Tilly's seminal hypothesis that 'states made war and war made states' are to say the least inadequate, even for European polities, let alone for Asian and European empires (Tilly I990 and Gennaioli and Prado 2012 disagree).

An alternative approach is to attempt to explain how and when Britain could be plausibly represented as a precocious case for fiscal achievement, combined with 
the formation of an effective centralised state and proceed to analyse the varied and complex histories behind mainland Europe's delayed and Asia's retarded development of states that also eventually became promotional for the transitions to industrial market economies (Vries 2015).

In I 8 I 5 , at the close of 23 years of warfare against Revolutionary and Napoleonic France, a German dynasty along with the aristocratic and plutocratic elites in charge of governing the, by then, United Kingdom of England, Wales, Scotland and Ireland, offered their deferential subjects superior standards of external security, internal stability, protection for property rights, support for traditional authority, legal frameworks for the extension and integration of markets, encouragement for technical and business innovation and, above all, more extensive and better protected access to imperial and other overseas markets than any other state in the world (Winch and O'Brien 2002).

When and how and why a small island realm moved on to a historical trajectory that culminated in geopolitical hegemony along with an early transition to an industrial market economy has been under intensified debate for more than two decades (O'Brien and Quinault I993). The bibliography is comprehensively referenced and surveyed in two recently published books by Peer Vries (Vries 2013, 2015). Trends in absolute and per capita levels of revenues from taxation received by the central governments of states (expressed in real terms) have been calibrated for the period I485-i8I5 (Karaman and Pamuk 20I3). For Britain and from i688 onwards the reconstructed data for taxation from I485 to I 688 can be linked to official statistics for taxes, to net receipts for credits and loans, as well as to annual figures for expenditures on debt servicing, civil government and the armed services. Simply put, what the English and (after union with Scotland in I707) the British data suggest from I 485 to the famous political crisis of civil war and republican rule $1640-60$ is an upswing from low and on-trend stable levels of tax revenues available to fund expenditures and to service the accumulation of a relatively small debt.

Thereafter official statistics display an increasingly clear, but cyclical, evolution towards ever higher levels of taxation, supporting and accompanied by an unprecedented accumulation of sovereign debt allocated in a very large degree to fund Britain's post-interregnum state's intensified and costly levels of engagements in warfare with rival European powers - initially the Netherlands and then for decades thereafter with France and Spain. During and after the Civil War by far the largest proportion (80 to 90 per cent) of the increment to total revenues from taxes and loans (net of transfers to service sovereign debt) was allocated by the state to sustain radically enlarged expenditures on the forces of the Crown, particularly the Royal Navy (O’Brien 2005; Bonney I999).

Of course the constitutional causes, course and outcomes of such a profound conjuncture in the political history of the off-shore island's monarchical regime cannot be represented by simplistic readings from a chronology of trends in its revenues and expenditures (Winch and O'Brien 2002). Nevertheless, in the course of a bloody and destructive Civil War and its aftermath of republican and military rule, a political 
consensus was reached and consolidated between the aristocratic and plutocratic elites who had united and rebelled in order to curtail the powers of the Crown and their royal royalist opponents. In outcome and despite concessions from the monarchy to respect the principle of regular Parliamentary meetings (ostensibly to exercise control over the state's revenues and expenditures managed by the king's appointed and dismissable ministers), between I660 and I8 I5, successive Parliaments operated on the basis of an unwritten fiscal constitution that reaffirmed the provision of adequate funding for the role of the military forces of the Crown as necessary for the preservation of internal order and protection of property. By default, Britain's assembly of notables (elected by some 2 per cent of the kingdom's adult population) also restored the prerogatives of monarchs and their advisers to declare, wage and fund wars that they deemed to be necessary for the defence and extension of British interests at home and overseas (O'Brien I988, 20 I Ia, b).

In constructing narratives dealing with the rise of Britain's fiscal-naval state, for several valid reasons most scholars in touch with the realm's seventeenth-century history begin with the interregnum of Civil War and its aftermath $\mathrm{I} 64 \mathrm{O}-83$. This conjuncture witnessed the reconstruction of the fiscal system, a sharp and persistent uplift in public investment in naval power for the defence of the realm and expansion overseas, the brutal containment of Catholic and Celtic threats to the unity of the kingdom, an altogether more aggressive commitment to a co-ordinated mercantilistic, foreign and commercial policy and the diffusion of a culture for the support of science. All of these shifts in the ideology of the British political elite emanated from the regrouping of an aristocratic and plutocratic consensus concerned with internal order and defence of the rights of property and privilege which was consolidated by a so-called 'Glorious Revolution'. Unfortunately, an altogether more inflated view of this 'Dutch coup d'état' of I 688 initiated by an article published by North and Weingast (1989) has led to a protracted debate among economists that has now been convincingly degraded by the evidence and arguments from historians with expertise on this period.

Historians insist that a range of political outcomes for the formation of an effective fiscal system flowed from the disorders and destruction of a major civil war, which facilitated a significant increase in the capacity of the island state to pursue an altogether more aggressive, costly and connected range of geopolitical, imperial and mercantilistic policies towards its European rivals (Hoppit 20I I; Gauci 20I I; O’Brien 2005; Vries 2015).

Given that liberal trade counterfactuals can be dismissed as anachronistic, adherence to a common set of mercantilistic policies provided all European elites with comparable advantages for the pursuit of power with profit including:

(a) enlarged bases for fiscal extraction, supporting the accumulation of sovereign debts;

(b) bullion reserves for the rapid mobilisation of armies and navies that also strengthened the basis for the extension of financial intermediation; 
(c) the agglomeration of economic activity in maritime cities, expanding upon the basis of exports and the processing of imported foodstuffs and raw materials.

Adam Smith's view that mercantilism denuded a potential for significant gains from trade and higher rates of growth is both laudable and plausible. Nevertheless, mercantilism (the dominant ideology of pre-modern western capitalism) generated pressures for fiscal centralisation to fund ever more expensive interludes of warfare which in turn may presumably have stimulated urbanisation with its familiar positive agglomerative and demographic externalities for economic growth. For the United Kingdom, persistently high levels of public investment in naval power for defence and aggression with imperial expansion overseas expanded opportunities to reap gains from trade and led after I805 to hegemonic 'command of the oceans' that created possibilities for a more benign liberal international economic order.

Given that the economic history of Britain between I65 I and I9I 4 can be plausibly represented as a paradigm case of successful mercantilism, Marc Bloch's recommendations for reciprocal comparisons lead logically to an inquiry into why the realm's leading rivals failed to countervail that small island state's perfidious and clear commitment to 'seizing' an inordinate share of the increasing gains from trade and imperialism from a world economy undergoing proto-globalisation (Hampson I988).

An answer to that meta-question involves close engagement with the complex political and geopolitical histories of France, Spain, Portugal, Genoa, Venice, the Netherlands, Denmark and other contenders for these gains. Historical research has concentrated on exposing and analysing contrasts with Britain in the access these major European states maintained after $165 \mathrm{I}-9$ to the fiscal, financial and other resources required for:

(a) the consolidation of their claims to sovereignty;

(b) the maintenance of stability and internal order;

(c) external security;

(d) and above all, for more profitable engagements in mercantilist competition and warfare with Britain maturing into Europe's naval superpower (Neal 2015).

Data to expose contrasts across Europe have been under collection and validation by networks of economic historians since the I990s. Statistics now available suggest that by the Peace of the Pyrenees (I659) the fiscal capacities of many states on the mainland to assess and collect taxes in order to fund expenditures and service loans for defence and aggression had been exhausted by more prolonged, expensive and indigenous warfare and had run into diminishing returns (Karaman and Pamuk 2013). Geopolitically this facilitated the rise of Britain because:

(a) political resistance to universal and centrally controlled systems of taxation remained far stronger among the 'confederated' polities on the continent (including the Netherlands);

(b) shares of taxes collected actually received by states on the mainland remained significantly lower; 
(c) Britain's relative detachment from European warfare from I453 to I65I and its short-lived Republican regime revealed that the realm possessed political, fiscal, natural, naval and other comparative advantages to realise the potential from an under-utilised tax base to become Europe's hegemonic geopolitical and economic power;

(d) fiscal centralisation came late to mainland Europe and in the wake of the Revolutionary and Napoleonic Wars. Control over expenditure also emerged gradually over the nineteenth century again for exogenous political reasons that historically were not correlated in any clear way to the constitutional forms of European states (Cardoso and Lains 2009; O’Brien 2008).

Major wars from I630 to I9I 4 represent Braudelian conjunctures in history that exercised profound influences on the political, institutional, social as well as the economic development of nations. The origins and causes of great power conflicts seem a lot less difficult to analyse than their effects. Their longer-term economic outcomes for national economies and the world economy as a whole remain problematical, both to conceptualise and seemingly impossible to measure (Tin-bor Hui 2005; Vries 20I5).

Classical political economy is marked by a laudable bias against armed conflict, but liberal economists may have been prone to exaggerate the malign effects of premodern warfare on manpower and capital formation, although war clearly disrupted and dislocated international economic relations and pushed national economies away from specialisation. None of the macro-elements of the major connections between wars and long-term economic growth has been or could be properly measured. Nevertheless, in thrall to the views of Adam Smith and David Ricardo, economic historians have been inclined to assert that losses from unrealised but potential gains from trade have been the most significant economic outcome of early modern mercantilist rivalry and warfare (Emmer et al. 2006). That outcome could be plausibly represented as possibly the most malign consequence of the Revolutionary and Napoleonic Wars from I793 to I8I9. Meanwhile the endeavours to measure the macro-economic impact of wars which can be plausibly represented as part of the process of the long-run growth of European or Asian economies may be an interesting but a chimerical scholarly pursuit (Thompson 2000; Holsti I99I).

Submitted: Io October 2016

Revised version submitted: 30 January 2017

Accepted: 6 February 2017 


\section{References}

AERTS, E. and CROUZET, F. (eds.) (I990). Economic Effects of the French Revolutionary and Napoleonic Wars. Leuven: Leuven University Press.

BACKHAUS, J. (2012). Navies and State Formation: The Schumpeter Hypothesis Revisited and Reflected. Berlin: LIT Verlag.

BELL, D. (2007). The First Total War: Napoleon's Europe and the Birth of Warfare. London: Bloomsbury. BESLEY, T. and PERSSON, T. (20 I I). Pillars of Prosperity: The Political Economics of Development Clusters. Princeton, NJ: Princeton University Press.

BONNEY, R. (ed.) (I995). Economic Systems and State Finance. Oxford: Clarendon Press.

BONNEY, R. (ed.) (I999). The Rise of the Fiscal State in Europe. Oxford: Oxford University Press.

BOOT, M. (2006). War Made New: Technology, Warfare and the Course of History. New York: Gotham Books

BOSKIN, M., FlEMMING, J. and GORINI, S. (eds.) (I987). Private Savings and Public Debt. Oxford: Oxford University Press.

BROADBERRY, S. (I988). The impact of world wars on the long run performance of the British economy. Oxford Review of Economic Policy, 4, pp. 25-37.

BROADBERRY, S. and HARRISON, M. (eds.) (2005). The Economics of War. Cambridge: Cambridge University Press.

BROADBERRY, S., CAMPBELL, B. M. S., KLEIN, A., OVERTON, M. and VAN LEEUWEN, B. (2015). British Economic Growth 1270-1870. Cambridge: Cambridge University Press.

CARDOSO, J. L. and LAINS, P. (2009). Paying for the Liberal State: The Rise of Public Finance in Nineteenth-Century Europe. Cambridge: Cambridge University.

CASELli, F. (ed.) (2008). Government Debts and Financial Markets in Europe. London: Pickering and Chatto.

CLODFELTER, M. (2002). Warfare and Armed Conflicts: A Statistical Guide to Casualty and Other Figures. Jefferson, NC: McFarland.

CONTAMINE, P. (ed.) (2000). War and Competition between States. Oxford: Clarendon Press

COOKSON, J. (I987). The British Armed Nation. Oxford: Oxford University Press.

DINCECCO, M. (20 I I). Political Transformations and Public Finances in Europe 1650-1913. Cambridge: Cambridge University Press.

DINCECCO, M. and ONORATO, M. (20I6). Military conflict and the rise of urban Europe. Journal of Economic Growth, 2I, pp. 259-82.

EDELSTEIN, M. (I990). What price cold war? Military spending and private investment in the United States I946-79. Cambridge Journal of Economics, I4, pp. 22 I-49.

EMMER, P. C., PÉTRÉ-GRENOUILlEAU, O. and ROITMAN, J. (eds.) (2006). A Deus ex Machina Revisited: Atlantic Colonial Trade and European Economic Development. Leiden: Brill.

EPSTEIN, L. (2000). Freedom and Growth: The Rise of States and Markets in Western Europe. London: Routledge.

FINDLAY, R., HENRIKSSON, G. H., LINDGREN, H. and LUNDAHL, M. (eds.) (2006). Eli Heckscher, International Trade and Economic History, part IV, Mercantilism. Cambridge, MA: MIT Press.

FINDLAY, R. and O'ROURKE, K. (2007). Power and Plenty: Trade, War and the World Economy in the Second Millennium. Princeton, NJ: Princeton University Press.

FRIEDMAN, B. (I984). The effects of large government deficits on interest rates and equity returns. Oxford Review of Economic Policy, I, pp. 58-74.

GATT, A. (2006). War in Human Civilization. Oxford: Oxford University Press.

GAUCI, P. (20I I). Regulating the British Economy 1660-1850. Farnham: Ashgate.

GENNAIOLI, N. and PRADO, M. (20I2). Warfare, fiscal capacity, and performance. Journal of Economic Growth, I67, pp. I7I-203.

GENNAIOLI, N. and VOTH, H.-J. (2015). State capacity and military conflict. Review of Economic Studies, 82, pp. I 409-48.

GOLDIN, C. and LEWIS, F. (I975). The economic cost of the American Civil War. Journal of Economic History, 35, pp. 66-77.

GOLDSTEIN, J. (1988). Long Cycles: Prosperity and War in the Modern Age. New Haven, CT: Yale University Press. 
HA-JOON, C. (2007). Institutional Change and Economic Development. Helsinki: United Nations University Press.

HALE, J. (1985). War and Society in Renaissance Europe 1450-1620. Baltimore: Baltimore University Press. HAMPSON, N. (1988). The Perfidy of Albion. Basingstoke: Macmillan.

HARRISON, M. (2O I 4). Capitalism at war. In L. Neal and J. Williamson (eds.), The Cambridge History of Capitalism, vol. II. Cambridge: Cambridge University Press.

HIU, V. (2005). War and State Formation in Ancient China and Early Modern Europe. Cambridge: Cambridge University Press.

HODGSON, G. (200I). How Economics Forgot History. London: Routledge.

HOFFMAN, P. (2016). Why Did Europe Conquer the World? Princeton, NJ: Princeton University Press.

HOLSTI, K. (I99I). Peace and War: Armed Conflicts and the International Order 1648-1989. Cambridge: Cambridge University Press.

HOPPIT, J. (20I I). The nation, the state and the first industrial revolution. Journal of British Studies, 50, pp. 307-3I.

KARAMAN, K. and PAMUK, S. (2013). Different paths to the modern state in Europe: the interaction between warfare, economic structure and political regime. American Political Science Review, I07, pp. 603-26.

KUZNETS, S. (1954). Post War Economic Growth. New Haven, CT: Yale University Press.

LANDERS, J. (2003). The Field and Forge: Population, Production and Power in the Pre-Industrial West. Oxford: Oxford University Press.

LEWIS, A. (1953). Economic Survey 1919-1939. London: Allen and Unwin.

LIBERMAN, P. (1998). Does Conquest Pay? Princeton, NJ: Princeton University Press.

MAGNUSON, L. (2009). Nation, State and the Industrial Revolution. London: Routledge.

MODELSKI, G. (1987). Long Cycles in World Politics. London: Macmillan.

MOKYR, J. (I989). Has the Industrial Revolution been crowded out? Some reflexions on Crafts and Williamson. Explorations in Economic History, 24, pp. 293-3I9.

NEAL, L. (1990). The Rise of Financial Capitalism. Cambridge: Cambridge University Press.

NEAL, L. (ed.) (20I5). The Cambridge History of Capitalism, vol. I: The Rise of Capitalism from Ancient Origins to 1848. Cambridge: Cambridge University Press.

NORTH, D. and WEINGAST, B. (I989). Constitutions and commitment: evolution of institutions governing public choice in seventeenth century England. Journal of Economic History, 49, pp. 803-32.

O'BRIEN, P. (I988). The political economy of British taxation. Economic History Review, 4I, pp. I-32.

O'BRIEN, P. (2005). Fiscal and financial conditions for the rise of British naval hegemony I 485-I 8 I 5 . London School of Economics Working Paper no. 9I.

O'BRIEN, P. (2008). Historical conditions for the evolution of a successful fiscal state: Great Britain and its European rivals from the Treaty of Munster to the Treaty of Vienna. In S. Cavaciochi (ed.), Fiscal Systems in the European Economy from the 13th to the 18th Centuries. Florence: Firenze University Press.

O'BRIEN, P. (2O I Ia). The contributions of warfare with Revolutionary and Napoleonic France to the consolidation and progress of the British Industrial Revolution. London School of Economics Working Paper no. I 50 .

O'BRIEN, P. (2OI Ib). The nature and historical evolution of an exceptional fiscal state and its possible significance for the precocious commercialization and industrialization of the British economy from Cromwell to Nelson. Economic History Review, 64, pp. 408-46.

O'BRIEN, P. and QUINAULT, R. (eds.) (1993). The Industrial Revolution and British Society. Cambridge: Cambridge University Press.

OVERY, R. (1997). Why the Allies Won. New York: Norton.

REINERT, S. (2O I I). Translating Empire: Emulation and the Origins of Political Economy. Cambridge, MA: Harvard University Press.

RUTTAN, V. (2006). Is War Necessary for Economic Growth? Military Procurement and Technological Development. Oxford: Oxford University Press.

SANDLER, T. and HARTLEY, K. (I995). The Economics of Defence. Cambridge: Cambridge University Press.

SANDLER, T. and HARTLEY, K. (eds.) (2007). A Handbook of Defense Economics. Amsterdam: Elsevier. SCHUMPETER, J. (1939). Business Cycles. New York: McGraw Hill. 
SILBERNER, E. (I946). The Problem of War in Nineteenth Century Economic Thought. Princeton, NJ: Princeton University Press.

THOMPSON, W. (2000). The Emergence of Global Political Economy. London: Routledge.

TILLY, C. (I990). Coercion, Capital and European States, AD 990-1990. Cambridge, MA: Blackwell.

TIN-BOR HUI, V. (2005). War and State Formation in Ancient China and Early Modern Europe. Cambridge: Cambridge University Press.

TORRES SÁNCHEZ, R. (ed.) (2007). War, State and Development: Fiscal Military States in the Eighteenth Century. Pamplona: University of Navarra Press.

VENTURA, J. and VOTH, H.-J. (20 I 5). Debt into growth, how sovereign debt accelerated the first industrial revolution. University of Zurich, Department of Economics, Working Paper no. I94.

VOIGTLANDER, N. and VOTH, H.-J. (2012). The three horsemen of riches, plague, war and urbanization in early modern Europe. Review of Economic Studies, 2, pp. $\mathrm{I}-38$.

VOIGTLANDER, N. and VOTH, H.-J. (20I3). Gifts of Mars: warfare and Europe's early rise to riches. Journal of Economic Perspectives, 27, pp. I65-86.

VRIES, P. (20I3). Escaping Poverty: The Origins of Modern Economic Growth, part 2, sections 25 and 26. Vienna: Vienna University Press.

VRIES, P. (2015). State, Economy and the Great Divergence: Great Britain and China 1680s-1850s. London: Bloomsbury.

WINCH, D. and O'BRIEN, P. (eds.) (2002). The Political Economy of British Historical Experience. Oxford: Oxford University Press.

YUN-CASALILLA, B. and O'BRIEN, P. (20I3). The Rise of Fiscal States: A Global History, $1500-1914$. Cambridge: Cambridge University Press.

ZURCHER, E.-J. (ed.) (2013). Fighting for a Living. Amsterdam: Amsterdam University Press. 